\title{
3 Research Square \\ The first hunting dog from Dmanisi: comments of social behaviour in Canidae and hominins
}

Saverio Bartolini Lucenti ( $\nabla$ sbartolinilu@unifi.it)

University of Florence

Joan Madurell-Malapeira

Institut Català de Paleontologia Miquel Crusafont

Bienvenido Martínez-Navarro

Catalan Institute of Human Paleoecology and Social Evolution

\section{Paul Palmqvist}

University of Malaga

Lorenzo Rook

University of Florence

David Lordkipanidze

Georgian National Museum

\section{Research Article}

Keywords: Human evolution, Hominini, Carnivorans, social behaviour

Posted Date: February 18th, 2021

DOI: https://doi.org/10.21203/rs.3.rs-201727/v1

License: (c) (i) This work is licensed under a Creative Commons Attribution 4.0 International License.

Read Full License

Version of Record: A version of this preprint was published at Scientific Reports on July 29th, 2021. See the published version at https://doi.org/10.1038/s41598-021-92818-4. 


\section{Abstract}

The renowned site of Dmanisi in Georgia, southern Caucasus (ca. 1.8 Ma) yielded the earliest direct evidence of hominin presence out of Africa. In this paper, we report the first record of a large-sized canid from this site, namely dentognathic remains, referable to a young adult individual that displays hypercarnivorous features (e.g., the reduction of $\mathrm{m} 1$ metaconid and entoconid) that allow us to include these specimens in the hypodigm of the late Early Pleistocene European species Canis (Xenocyon) lycaonoides.

Much fossil evidence suggests that this species was a cooperative pack-hunter that, unlike other largesized canids, was capable of social care toward kin and non-kin members of its group. Interestingly, this rather derived hypercarnivorous canid attests to one of the earliest records in Dmanisi. Its dispersal from Asia to Europe and Africa followed a parallel route to that of hominins, but in the opposite direction. Hominins and hunting dogs, both recorded in Dmanisi at the beginning of their dispersal across the Old World, are the only two Early Pleistocene mammal species with proved altruistic behaviour towards their group members, an issue discussed over more than one century in evolutionary biology.

\section{Introduction}

Wild dogs are medium- to large-sized canids that possess several hypercarnivorous craniodental features and complex social and predatory behaviours (i.e., social hierarchic groups and pack-hunting of large vertebrate prey typically as large as or larger than themselves). Two extant species of wild dogs survive in the Old World, the Indian dhole, Cuon alpinus (Pallas, 1811), and the African hunting dog, Lycaon pictus (Temminck, 1820). Both species are nowadays endangered or critically endangered according to the IUCN red list of threatened species ${ }^{1,2}$. The African hunting dog, known also as painted dog, and the dhole are among the top predators in their respective habitats ${ }^{3,4}$ thanks to the combination of a number of dental hypercarnivorous traits, skeletal adaptations to cursorial pack hunting and their social behaviour.

The evolution of these hypercarnivorous canids is still unknown and open to debate ${ }^{5,6}$.

Furthermore, there is also a great deal of confusion in the taxonomy of the extinct large-sized and hypercarnivorous canids, which use to be referred to different systematic denominations (see Supp. Inform.). Such names often hint implied or proposed affinities to extant taxa, yet seldomly based on phylogenetic analyses. Considering the results of molecular phylogenies ${ }^{7,8}$, from which it is evident that Lycaon and Cuon are sister taxa of the crown group of Canis, and that the large-sized members of the genus Xenocyon might be related to both Lycaon and Cuon, here we preferred to avoid names suggestive of a closer relationship to any of both genera, privileging the more parsimonious denomination Canis (Xenocyon) (see the Supp. Inform. for an in-depth discussion of the taxonomical issues).

The earliest record of a species of this group of hypercarnivorous canids corresponds to Canis (Xenocyon) cf. dubius Teilhard de Chardin (1940), which is represented by a single hemimandible ${ }^{6}$ from 
the Zanda Basin (3.81-3.42 Ma; Fig. 1). The species $C$. (Xenocyon) dubius is generally related to the lineage of $\mathrm{Cuon}^{6,9}$. A younger but more complete specimen from Fan Tsun (Taigu ${ }^{10}$ ) was ascribed to Canis (Xenocyon) antonii (ca. $2.5 \mathrm{Ma})^{11}$. The latter canid is large-sized and displays evident dental features hinting to an incipient adaptation to a hypercarnivorous diet. Other records of large-sized canids with hypercarnivorous features are rather scanty across Eurasia and are of difficult attribution, considering the presence of hypercarnivorous Canis s.s. in Asia during the Early Pleistocene, e.g., Canis chihliensis Zdansky, 1924; Canis teilhardi Qiu et al., 2004; or Canis yuanmoensis You \& Qi, 1973 (like in North American Canis dirus Leidy, 1858, see $^{10}$ ).

Around 2.0-1.8 Ma, different forms appeared in several parts of the Old World. These forms showed distinctive dental features (i.e., broad and stoutly-built carnassials with enlarged buccal cuspids), coupled with craniomandibular ones (robust mandibles and developed frontal sinuses). Their large size combined to these dental adaptations could have determined an advantage over the contemporaneous, mediumsized mesocarnivorous canids, as testified by the westward dispersion and radiation of Canis (Xenocyon) falconeri (Forsyth Major, 1877) in Western Europe and of Canis (Xenocyon) africanus (Pohle, 1928) from Olduvai Bed I in Africa. A close relationship between both taxa was suggested by 5,11 who regarded them as the ancestor of modern L. pictus. However, such interpretation has not been shared by other researchers ${ }^{12}$. Recently, a new large-sized taxon was described as Lycaon sekowei Hartstone-Rose et al. (2010), with fragmented cranial material from Cooper's Cave in South Africa (ca. 1.9 Ma) and an almost complete skeleton from Gladysvale (ca. $1.0 \mathrm{Ma})^{13}$. Some of the morphologies of the holotype from Cooper's Cave (i.e., the high-crowned upper premolars, their mesial occlusal morphology, the lingual projection of P4 protocone, and the relative buccolingual length of the M1) cast doubts on its taxonomical attribution and its actual relation with Canis (Xenocyon)'s group. Moreover, the upper teeth resemble those of the Asian $C$. chihliensis, a large-sized canid possibly belonging to a hypercarnivorous lineage of Canis $^{10}$.

During the late Early Pleistocene (i.e., Calabrian; 1.8-0.8 Ma), while other more primitive species remained in Africa [e.g., Canis (Xenocyon) atrox Broom ${ }^{14}$ in Kroomdrai A; Fig. 1] a more derived form of Canis (Xenocyon) appeared and became widespread across the whole Old World (Fig. 1). Canis (Xenocyon) lycaonoides (Kretzoi, 1938) was a large-sized canid that resembled $C$. (Xenocyon) gr. falconeri but with more derived craniodental features (e.g., the P4 protocone tends to attach to the tooth; the M1 metaconule is crest-like; the M1 talon is reduced; the $\mathrm{m} 1$ hypoconid is enlarged and tends to be centred in the talonid; the entoconid is reduced, being represented by a small crest-like cuspulid; and the $\mathrm{m} 3$ is single cusped). Its earliest record appears to be that of Tamagawa River near Tokyo (Japan, 15; Fig. 1). This locality is loosely dated to $2.1-1.6 \mathrm{Ma}$, based on the associated fauna and ichnofauna ${ }^{16}$. In spite of its uncertain chronology, this early occurrence suggests an eastern Asian origin for this hypercarnivorous species. Subsequently, during the late Early Pleistocene and the base of the Middle Pleistocene, from 1.8 to $0.7 \mathrm{Ma}, C$. (Xenocyon) lycaonoides became one of the most common and important members of the carnivoran palaeoguild of Eurasia (Fig. 1). Moreover, C. (Xenocyon) lycaonoides dispersed also in Africa, where it is documented in the northern and eastern part of the continent (e.g., Olduvai Bed Il; Fig. 1). 
Considering the overall cranial morphology and its dental features, which confirm the original interpretation by Kretzoi ${ }^{17}$, Martínez-Navarro \& Rook ${ }^{5}$ deemed $C$. (Xenocyon) lycaonoides as strictly related to extant $L$. pictus. Similar conclusions were shared by several other scholars ${ }^{10,18}$, who supported also a Eurasian origin for the living African hunting dog.

Among extant Carnivora, Lycaon pictus has one of the most complex, structured and unique social behaviours ${ }^{3}$. As one of the closest relatives to L. pictus, C. (Xenocyon) lycaonoides, the Eurasian hunting dog, might have had comparable complex sociality. Carbone and co-authors ${ }^{19}$ showed that the metabolic energy requirements for large-sized species $(<21.5 \mathrm{~kg})$ force them to hunt prey larger than themselves and thus, in hypercarnivorous Canidae, cooperatively. As such, this element allows us to figure the social behaviour of extinct hypercarnivorous canids, even with limited direct evidence. Nevertheless, apart from indirect and inferred evidence, direct proof of social behaviour in the Eurasian hunting dog have been proposed $^{20,21}$.

Here we report the first occurrence of wild dogs from the Georgian site of Dmanisi (Fig. 1; 1.78-1.76 $\mathrm{Ma})^{22}$. This locality preserves an outstanding fossil record, both in terms of abundance, completeness of skeletal remains and preservation status, as testified by the recently described molecular phylogeny based on a fossil rhino tooth ${ }^{23}$. In this paper, we describe the newly discovered remains, identifying them taxonomically and interpreting in the frame of Early Pleistocene diversity of Canis (Xenocyon). Moreover, the site of Dmanisi yielded the earliest direct evidence of hominin presence out of Africa in their dispersal throughout Eurasia 24,25 with also indication of complex sociality among individuals of this population ${ }^{26,27}$. The co-occurrence of two highly social species in the same site at 2.0-1.8 Ma, a time of extreme diversification and expansion of the two clades $^{5,6}$ from their centre of origin, raises interest in the role played by social behaviour and by mutually-beneficial cooperation and reciprocity in the geographic expansion of these species. Questions to be explored in this paper.

\section{Results}

Implications for fossil Hunting dogs Diversity. The discovery of a large-sized canid in the Georgian site of Dmanisi represents an important discovery adding valuable information to the current knowledge of canid radiation during the second half of the Early Pleistocene (early Calabrian). Despite the fragmented nature of the specimens, the set of features possessed by D6327 (Fig. 2A-F and Augmented Reality content) allow a confident attribution to Canis (Xenocyon) lycaonoides (see Supplementary Information), the plausible ancestor of extant African hunting dog ${ }^{5,18}$. As such, this record is the oldest occurrence of Eurasian hunting dog, and it precedes burst of dispersion that the species experienced across the entire Old World during the Calabrian $5,10,15$.

Dietary preferences of Dmanisi Hunting dog. In order to test the dietary adaptations of the Dmanisi hunting dog and other Early Pleistocene forms, a linear discriminant analysis was performed over the extant canids (31 species, 244 specimens; craniodental measurements kindly provided by B. Van 
Valkenburgh), which were grouped in two feeding groups: (i) omnivores (i.e., meso- and hypocarnivores; 27 extant species, 210 specimens), in which vertebrate flesh represents less than $70 \%$ of their dietary requirements; and (ii) hypercarnivores (four extant species, 34 specimens), which diet consists almost entirely of vertebrate flesh and are pack-hunters of prey as large as or larger than themselves. Seven metric variables of this dataset for which the measurements were available in the Dmanisi specimens were used in the analysis: length and breadth of the third lower premolar ( $\mathrm{p} 3 \mathrm{~L}$ and p3B, respectively), length and breadth of the trigonid basin of the lower carnassial ( $\mathrm{m} 1$ trig $\mathrm{L}$ and $\mathrm{m} 1 \mathrm{trigB}$, respectively), length and breadth of the talonid basin of the lower carnassial ( $\mathrm{m} 1 \mathrm{tal}$ and $\mathrm{m} 1 \mathrm{talB}$, respectively), and jaw depth measured at the limit between p3 and p4 (JDp4). The linear discriminant function, obtained with cross validations using the leave one out method, correctly allocated $98.8 \%$ of the specimens to their feeding group (Fig. 3). Indeed, all omnivores and all hypercarnivores, apart from the four specimens of the small-sized S. venaticus, were correctly classified (Fig. 3). According to the loadings of the variables in the discriminant function, the hypercarnivores show third premolars that are relatively mesiodistally shorter and buccolingually narrower compared to those of omnivorous species, as well as a carnassial with an enlarged trigonid blade and a reduced talonid basin, and a deeper, more stoutly-built corpus, which is in agreement with previous analyses of adaptations in canids towards hypercarnivory ${ }^{28,29}$. This function reclassified unequivocally the individual from Dmanisi (values of the variables obtained from D6327) in the group of hypercarnivores (Fig. 3), with a probability of pertinence of 0.97 . The two specimens of $C$. (Xenocyon) lycaonoides from Venta Micena (a site that is slightly younger in age than Dmanisi, ca 1.6 Ma) for which these measurements were available were also classified as hypercarnivores. However, they show higher scores in the discriminant function, close to the group centroid of hypercarnivores. Similarly, the specimen from Untermassfeld, a site of Jaramillo age, (ca. 1.0 $\mathrm{Ma}$ ), shows the highest scores among the fossil hunting dogs, which reflects its more advanced adaptations towards hypercarnivory, similar to those of extant African hunting dogs. These results confirm that the craniodental morphological features of the Eurasian hunting dog from Dmanisi (Fig. 2) were well suited for a diet consisting exclusively of vertebrate flesh. Moreover, it shows that there was a gradual evolution of these craniodental adaptations in $C$. (Xenocyon) lycaonoides from the oldest members of the lineage to the most derived ones, confirming the morphological evidence, as pointed out by other scholars $5,10,18,30$.

\section{Discussion}

Dmanisi, located near the crossway between Africa and Eurasia, is a key site to explain the dispersal large mammal species, in a time of great faunal turnovers in the whole Old World ${ }^{31,32}$. This Georgian site also records the earliest direct evidence of hominin out of Africa and into Eurasia, at ca. 1.8 Ma. Here, we report the record of the Eurasian hunting dog, $C$. (Xenocyon) lycaonoides, which testifies to the beginning of the dispersal of this more derived, frankly hypercarnivorous canids from its eastern Asia region of origin, similarly to Canis borjgali Bartolini Lucenti et al., 2020 (the mesocarnivorous, wolf-like species also recorded in Dmanisi ${ }^{33}$ ). During the Calabrian $C$. (Xenocyon) lycaonoides became a common element of the entire Old-World faunas during the late Early-early Middle Pleistocen ${ }^{18}$, when it even reached North 
America ${ }^{10}$. In this dispersal, the Eurasian hunting dog followed at the same time the same dispersal pattern of hominids, just in the opposite direction. The co-occurrences of both species along their dispersal routes together with some other large-sized carnivore taxa, for instance the dirk-toothed cat of African origin Megantereon whitei (Broom, 1937), suggest that the ecological conditions favoured the dispersal of these species at that time. Large-sized carnivorans like this felid has been recognized as important supplier of scavengeable resources for the hominins in direct competition with the supercarrion-eater Pachycrocuta brevirostris ${ }^{34,35}$.

Social behaviour of Canis (Xenocyon) and Homo in the late Early Pleistocene. "There is, at the same time, as much, or perhaps even more, of mutual support, mutual aid, and mutual defense: Sociability is as much a law of nature as mutual struggle" 36 . Probably, the most relevant common feature between the extinct hominins and the fossil hunting dogs is the fossil evidence on the mutually-beneficial cooperation, reciprocity and social behaviour ${ }^{37}$ of both species. This is well documented in Dmanisi by the finding at this site of an edentulous individual of Homo erectus (composite skull D 3444/D 3900) who lost all but one of its teeth several years before the time of its death, as evidenced by extensive bone loss in the maxilla and mandible due to resorption of the tooth alveoli. This old individual could not chew its hard or coriaceous food by itself, which means that its survival after the loss of the majority of its teeth probably relied on the assistance from other members of the family group ${ }^{26}$ (Fig. 4A). As it has been noted 26,27 this kind of altruistic behaviour is beyond forms of biological altruism, proper of non-primate mammals or even "non-human primates"27. This suggests that altruistic behaviour and care of the elderly might have developed very early in hominins, at least two million years ago 26,27 . Among Carnivora, social behaviour is frequent, considering the numerous benefits that cooperation offers to carnivorans (increased breeding success and individual survival; enhanced hunting success; ability to kill on larger prey; deterrent and strength against kleptoparasites; help for the rearing of pups ${ }^{38,39}$. Canidae have some of the best-known examples of social organization of all mammals (e.g., the grey wolf, C. Iupus ${ }^{40}$ ). Probably less known, yet interesting is the case of the African hunting dogs. This hypercarnivore species display a more complex and peculiar set of behaviour, unique among Canidae, if not carnivorans. This includes exclusive cooperative hunt, obligate cooperative breeding ${ }^{41}$ and prioritized access of the pups to the kills ${ }^{3}$. Many authors ${ }^{42}$ noted a reduced degree of aggressivity between pack members in comparison to other social Canidae (C. Iupus and Cuon alpinus ${ }^{40}$ ) even during the consumption of the kill ${ }^{3}$.

Sociality in fossil canids had been investigated by numerous authors ${ }^{43}$ and Carbone and coauthors ${ }^{19}$ proved the necessity for large canids, weighing more than $21.5 \mathrm{~kg}$, to hunt cooperatively to kill on prey larger than themselves. The $C$. (Xenocyon) lycaonoides is indeed a large-sized hypercarnivorous species. Body-size estimates suggests that this canid was similar to L. pictus (whose average weight is $20-25 \mathrm{~kg}$ (44)) if not larger (estimated weight of $C$. (Xenocyon) lycaonoides $=28 \mathrm{~kg},(20)$ ). The individual from Dmanisi, despite being a young adult, would have been rather robust (around $30 \mathrm{~kg}$, applying the regression equation of Van Valkenburgh ${ }^{45}$ ). Such a body mass, coupled with its marked hypercarnivorous features, support the idea that $C$. (Xenocyon) lycaonoides adopted cooperative hunting 
strategies, similar to the extant canids, C. lupus, C. alpinus and L. pictus. Further support of a highly social group organization is provided by fossil pathological specimens. Recently, Tong et al. ${ }^{21}$ described injuries in the sample of Shanshenmiaozui, Nihewan Basin, dated to 1.2 Ma. One of them records a dental infection likely inflicted by processing hard food, such as bone; the other suffered a displaced fracture of its tibia and, despite such a severe injury (which would represent a death sentence for a solitary predator) it managed to survive the trauma to heal. The long period that was presumably required for healing the compound fracture, as well as the incapacitating nature of this trauma for a cursorial predator during the rest of its life (as the healed tibia was considerably shortened), suggests social hunting strategies and provision by other members of the family/pack (primarily food-sharing). Similar pathologies have been also detected in the Late Pleistocene population of Canis dirus Leidy, 1858 from La Brea tar pits in southern California ${ }^{46}$. This is not surprising considering that packs of extant canids temporarily support wounded or sick members of their group, as reported by many authors in both extant C. Iupus and L. pictus ${ }^{39}$, despite the cost in terms of efficiency of the group ${ }^{47}$. Nevertheless, in the case of African hunting dogs, several studies describe the tolerance by group members not only for injured, but also for disabled or old individuals at the kills ${ }^{39,48}$. Furthermore, disabled or old African hunting dogs receive food by fellow pack members via regurgitation 39,49 , a way of food-sharing that other canids reserve exclusively to kin, very rarely non-kin, pups and to the breeding female. The fossil record yields evidence of similar behaviour in extinct hunting dog as well. An altruistic behaviour of food provisioning to disabled individuals was documented in $C$. (Xenocyon) lycaonoides at the site of Venta Micena (Fig. 4B). Here a nearly complete cranium with a mandible preserved in anatomical connection were unearthed (skull VM-7000) ${ }^{20}$. This skull belonged to a 7-8 years-old individual (considering the moderate-heavy dental wear of its teeth). By far the most sticking features of this specimen are the high degree of cranial fluctuating asymmetry and several tooth anomalies, including dental agenesia of the upper right canine, the P3 and $\mathrm{m} 3$. These teeth were not broken or lost during the life of the individual, as showed by CTscans and radiographs of the cranium ${ }^{20}$. The dental alveolus of the right upper canine is completely absent, as for the other teeth ${ }^{20}$. Moreover, the right $\mathrm{m} 2$ is missing and its alveolus is partially reabsorbed. The malformations of the $C$. (Xenocyon) lycaonoides from Venta Micena were probably due to developmental instabilities resulting from a high level of genetic homozygosity in the relatively small population of wild dogs that inhabited the Baza Basin during late Early Pleistocene times ${ }^{20}$. However, despite the numerous congenital disabilities, the individual VM-7000 was able to reach adulthood, which probably affected or even precluded its ability in the pack-hunting activities (Fig. 4B). This suggests that cooperative behaviour and food provisioning from other members of the family group were the only way for this individual to survive until this age $\mathrm{e}^{20}$. Similarly, to the old human from Dmanisi, who managed to reach such an old age thanks to the altruistic help and care of other family members (Fig. 4A), this hunting dog reached adulthood.

Therefore, these findings apparently suggest that increased cooperation and altruistic behaviour may have been important factors for the survival and dispersal of both humans and large social carnivorans in the open environments of Africa, Eurasia and North America. Interestingly, hunting dogs and hominids 
are up to now the only late Early Pleistocene highly-social species with proved altruistic behaviour towards other members of their group, including food sharing to group members. Such a behaviour is specially developed in extant African hunting dogs, where individuals with limitations resulting from genetic abnormalities, pathologies and/or advanced age are helped and sustained by the other members of the family group $39,41,42$. Canis (Xenocyon) lycaonoides showed a similar pattern cooperative and altruistic behaviour towards pack-members ${ }^{20,21}$. The occurrence of the Eurasian hunting dog in Dmanisi marks one the first and better chronologically-constrained record of this large-sized, pack-hunter canid. The success of this wide-ranging dispersion across continents 5,10 , unprecedented and never reached by any other large-sized canids, might be correlated also to the advantages of the mutually-beneficial cooperation and altruistic nature of these fossil hunting dogs, as the result of an evolutionary tendence leading to co-operation among members of a species: "the best pathway to advantage for individuals" 50 .

It would not be necessary, but we have here a new evidence of the importance of Dmanisi for that, paraphrasing Dawkins ${ }^{51}$, Homo and highly social Canidae both are descended from highly social ancestors and their ancestors lived in groups; this was not an option but an essential survival strategy and from this mutual aid arose.

\section{Materials And Methods}

The present study is based on the comparative morphological analysis of the large-sized Canis (Xenocyon) from Dmanisi and other Plio-Pleistocene hypercarnivorous canids of the Old World. The described fossils are housed at the S. Janashia Museum of Georgia, Georgian National Museum (Tbilisi) (MG-GNM). As comparative fossil material, the Villafranchian and Epivillafranchian canids from the Old World and North America housed at AMNH, AUT, ICP, IGF, and MNHN (see abbreviations below) were studied. This fossil comparative sample includes specimens of Canis (Xenocyon) dubius from Zhoukoudian ${ }^{52}$. Canis (Xenocyon) falconeri from Upper Valdarno Basin. Canis (Xenocyon) lycaonoides from Apollonia-153; Campbellpore ${ }^{11}$; Chukochya, Zanushino ${ }^{30}$; Cripple Creek Sump ${ }^{10}$; Cueva Victoria, Vallparadís Estació ${ }^{18}$; Lakhuti-2 ${ }^{11,30}$; Ma Fang ${ }^{11}$; Nalaikha ${ }^{30}$; Olduvai Bed II5; Pirro Nord ${ }^{54}$; Tamagawa river $^{15}$; Tighennif ${ }^{55}$; Trlica $^{56}$; Untermassfeld ${ }^{30}$; Venta Micena ${ }^{20}$; Westbury-sub-Mendip ${ }^{57}$. Canischihliensis from Yushe Basin ${ }^{11}$. The relevant literature on these canids was reviewed ${ }^{6,10,13,14,30,52,54-55,58-59}$.

Extant specimens housed at the AMNH, MZUF, ICP, RMCA and MG-GNM (see abbreviations below) were also used for morphological and metrical comparisons. We examined specimens of Canislupus Linnaeus, 1758, and Lycaonpictus (Temminck, 1820). Moreover, a wide data set of craniodental measurements taken in modern canids ( 244 specimens from 31 species) by Prof. Blaire Van Valkenburgh was used also in some statistical comparisons, including a discriminant analysis between omnivorous (i.e., meso- and hypocarnivorous) and hypercarnivorous canids, in order to deliver palaeoecological inferences for the Dmanisi wild dogs and also for others from different (and younger) sites, like Venta Micena in Spain and Untermassfeld in Germany. 
Cranial and dental measurements were taken with a digital calliper to the nearest $0.1 \mathrm{~mm}$ following von den Driesch ${ }^{60}$ with minor modifications.

Abbreviations. AMNH, American Museum of Natural History, New York (United States); AUT, Earth Science Department of Aristotle University of Thessaloniki; D, Dmanisi site; ICP, Institut Català de Paleontologia Miquel Crusafont, Universitat Autònoma de Barcelona (Cerdanyola del Vallès, Barcelona, Spain); IGF, Museum of Natural History, Geological and Paleontological section, the University of Florence (Italy); MGGNM, S. Janashia Museum of Georgia, Georgian National Museum (Tbilisi, Georgia); MZUF, Museum of Natural History, "La Specola" Zoology section, University of Florence (Italy); RMCA, Royal Museum for Central Africa, Tervuren (Belgium).

\section{Data Availability}

All data generated or analyzed during this study are included in this published article (and its Supplementary Information Files)

\section{Declarations}

\section{Acknowledgments}

The authors are indebted to the kindness and availability of the curators who granted access to the collections of their institutions and museums: M. Bukhsianidze MG-GNM; P. Agnelli of MZUF; E. Cioppi of IGF; J. Galkin, and J. Meng of the AMNH; G. Koufos of AUT and E. Gilissen and W. Wendelen from RMCA. The Italian Embassy in Georgia offered continuous support to LR and SBL while working in Tbilisi.

The Italian Ministry for Foreign Affairs (DGPCC-V) is acknowledged for financially supporting Italian paleontological research in Georgia. This study has been funded by the University of Florence (Fonti di Ateneo, to LR), the Spanish Agencia Estatal de Investigación (grants CGL2016-78577-P, CGL2016-80975P, CGL2017-82654-P, AEI/FEDER-UE) and the Generalitat de Catalunya (CERCA Program GENCAT 2017SGR 859; SGR 416 GRC, AGAUR, Generalitat de Catalunya). Part of this research was also funded by the Synthesys project to JMM (BE-TAF-5471).

\section{Author Contributions}

S.B.L., J.M.-M, B.M.N, P.P., L.R. and D.L conceived and designed the experiments. S.B.L., J.M.-M, B.M.N, P.P. and L.R. wrote the paper and prepared figures and tables. All authors analyzed the data and reviewed drafts of the paper.

\section{Competing Interest}

The authors declare no competing interests.

\section{References}


1. Jdeidi, T., Masseti, M., Nader, I., de Smet, K., \& Cuzin, F. Lycaon pictus. The IUCN Red List of Threatened Species 2010. doi:10.1371/journal.pone.0073856 (2010).

2. Kamler, J. F. et al. Cuon alpinus. The IUCN Red List of Threatened Species 2015. e.T5953A72477893 (2015.).

3. McNutt, J. W. \& Woodroffe R. Lycaon pictus African Wild Dog (Painted Dog, Hunting Dog) In Mammals of Africa: Volume V: Carnivores, Pangolins, Equids and Rhinoceroses, (Ed. Kingdon, J.) 51-59 (A\&C Black, 2014).

4. Nurvianto, S., Eprilurahman, R., Imron, M. A, Herzog, S. Feeding habits of pack living dhole (Cuon alpinus) in a dry deciduous forest of East Java, Indonesia. Taprobanica 8, 10-20 (2016).

5. Martínez-Navarro, B. \& Rook L. Gradual evolution in the African hunting dog lineage Systematic implications. R. Palevol 2, 695-702 (2003).

6. Wang, X., Li, Q., Xie, G. Earliest record of Sinicuon in Zanda Basin, southern Tibet and implications for hypercarnivores in cold environments. Int. 355, 3-10 (2014).

7. Koepfli, K. P. et al. Genome-wide evidence reveals that African and Eurasian golden jackals are distinct species. Biol. 25, 2158-2165 (2015).

8. Gopalakrishnan, S. et al. Interspecific Gene Flow Shaped the Evolution of the Genus Canis. Biol. 28, 3441-3449.e5 (2018).

9. Qiu, Z., Deng, T., Wang, B. Early Pleistocene mammalian fauna from Longdan, Dongxiang, Gansu, China. Sin. 27, 1-252 (2004).

10. Tedford, R. H., Wang, X., Taylor, B. E. Phylogenetic Systematics of the North American Fossil Caninae (Carnivora: Canidae). Am. Museum Nat. Hist. 325, 1-218 (2009).

11. Rook, L. The Plio-Pleistocene Old World Canis (Xenocyon) ex gr. falconeri. Soc. Paleontol. Ital. 33, 71-82 (1994).

12. Lewis, M. E. \& Werdelin, L. Patterns of change in the Plio-Pleistocene carnivorans of eastern Africa In Hominin Environments in the East African Pliocene: An Assessment of the Faunal Evidence, (Eds. R. Bobe, Z. Alemseged, A.K. Behrensmeyer) 77-105 (2007).

13. Hartstone-Rose, A., Werdelin, L., De Ruiter, D. J., Berger, L. \& Churchill, S. E. The Plio-Pleistocene Ancestor of Wild Dogs, Lycaon sekowei sp. J. Paleontol. 84, 299-308 (2010).

14. Broom, R. \& Schepers, G. W. H. The South African fossil ape-men: the Australopithecinae (No. 2). Pretoria: Transvaal Museum (1946).

15. Koizumi, A. First Record of the Plio-Pleistocene Hypercarnivorous canid, Canis (Xenocyon) falconeri from Tama River. Res. 42, 105-111 (2003).

16. Matsukawa, M., Kakinuma, H., Baba, K. \& Ohira, H. Stratigraphy and correlation of the PlioPleistocene strata along the western flank of the Kwanto Plain, Japan. Tokyo Gakugei University 58,173-202 (2006).

17. Kretzoi, M. Die Raubtiere von Gombaszög nebst einer übersicht der Gesamtfauna (Ein beitrag zur stratigraphie des Altquartaers). Mus.Natl Hung. 31, 88-157 (1938). 
18. Madurell-Malapeira, J. et al. The latest European painted dog. Vertebr. Paleontol. 33, 1-6 (2013).

19. Carbone, C., Teacher, A. \& Rowcliffe, J. M. The costs of carnivory. PLoS Biol. 5, e22 (2007).

20. Palmqvist, P., Arribas, A. \& Martínez-Navarro, B. Ecomorphological study of large canids from the lower Pleistocene of southeastern Spain. Lethaia 32, 75-88 (1999).

21. Tong, $\mathrm{H}$. et al. Hypercarnivorous teeth and healed injuries to Canis chihliensis from Early Pleistocene Nihewan beds, China, support social hunting for ancestral wolves. PeerJ 0-22 (2020). doi:10.7717/peerj.9858

22. Ferring, R. et al. Earliest human occupations at Dmanisi (Georgian Caucasus) dated to 1.85-1.78 Ma. Pnas 108, 10432-10436 (2011).

23. Cappellini, E. et al. Early Pleistocene enamel proteome from Dmanisi resolves Stephanorhinus Nature 574, 103-107 (2019).

24. Lordkipanidze, D. et al. Postcranial evidence from early Homo from Dmanisi, Georgia. Nature 449, 305-310 (2007).

25. Lordkipanidze, D. et al. A complete skull from Dmanisi, Georgia, and the evolutionary biology of early Homo. Science 342, 326-331 (2013).

26. Lordkipanidze, D. et al. The earliest toothless hominin skull. Nature 434, 717-718 (2005).

27. Lordkipanidze, D. et al. A fourth hominin skull from Dmanisi, Georgia. Rec. 288, 1146-1157 (2006).

28. Van Valkenburgh, B. Iterative evolution of hypercarnivory in canids (Mammalia: Carnivora): Evolutionary interactions among sympatric predators. Paleobiology 17, 340-362 (1991).

29. Balisi, M. A. \& Van Valkenburgh B. Iterative evolution of large-bodied hypercarnivory in canids benefits species but not clades. Biol. 3, e461 (2020).

30. Sotnikova, V. Remains of Canidae from the lower Pleistocene site of Untermassfeld In Das Pleistozän von Untermassfeld bei Meiningen (Thüringen) (ed. R. D. Kahlke) 607-632 (Römisch-Germanisches Zentralmuseum, 2001).

31. Rook, L. \& Martínez-Navarro, B. Villafranchian: the long story of a Plio-Pleistocene European large mammal biochronologic unit. Int.219,134-144 (2010).

32. Azzaroli, A., De Giuli, C., Ficcarelli, G. \& Torre, D. Late Pliocene to early Mid-Pleistocene mammals in Eurasia: Faunal succession and dispersal events. Palaeoclimat. Palaeoecol. 66, 77-100 (1988).

33. Bartolini Lucenti, S., Bukhsianidze, M., Martínez-Navarro, B. \& Lordkipanidze, D. The Wolf from Dmanisi and Augmented Reality: Review, Implications, and Opportunities. Earth Sci. 8, 1-13 (2020).

34. Espigares M. P. et al. Homo Pachycrocuta: earliest evidence of competition for an elephant carcass between scavengers at Fuente Nueva-3 (Orce, Spain). Quat. Int. 295, 113-125 (2013).

35. Madurell-Malapeira, J. et al. Were large carnivorans and great climatic shifts limiting factors for hominin dispersals? Evidence of the activity of Pachycrocuta brevirostris during the Mid-Pleistocene Revolution in the Vallparadís Section (Vallès-Penedès Basin, Iberian Peninsula). Int. 431, 42-52 (2017).

36. Kropotkin, P. Mutual Aid, A Factor of Evolution (McClure P. \& Co., New York, 1902) 348 pp. 
37. Boucher, D. H. The Biology of Mutualism: Ecology and Evolution (New York: Oxford University Press, 1985).

38. Almberg, E. S. Social living mitigates the costs of a chronic illness in a cooperative carnivore. Lett. 18, 660-667 (2015).

39. Courchamp, F. \& Macdonald, D. W. Crucial importance of pack size in the African wild dog Lycaon pictus. Conserv. 4, 169-174 (2001).

40. Mech, L. D. Canis lupus. Species 37, 1-6 (1974).

41. Woodroffe, R., Lindsey, P. A., Romañach, S. S. \& Ranah, S. M. O. African wild dogs (Lycaon pictus) can subsist on small prey: implications for conservation. Mammal. 88, 181-193 (2007).

42. Schaller, G. B. The Serengeti lion: a study of predator-prey relations (University of Chicago Press, 1970).

43. Van Valkenburgh, B., Sacco, T. \& Wang, X. Chapter 7: pack hunting in Miocene borophagine dogs: evidence from craniodental morphology and body size. Am. Mus. Nat. Hist. 279, 147-162 (2003).

44. Castelló, J. R. Canids of the World: Wolves, Wild Dogs, Foxes, Jackals, Coyotes, and Their Relatives (Princeton University Press, 2018).

45. Van Valkenburgh, B. Iterative evolution of hypercarnivory in canids (Mammalia: Carnivora): Evolutionary interactions among sympatric predators. Paleobiology 17, 340-362 (1991).

46. Lawler, D. F., Widga, C. \& Smith, G. K. Observations of the acetabulum and proximal femur of the dire wolf (Canis dirus, Leidy 1854). Vet Anat. 10, 73-83 (2017).

47. Courchamp, F., Rasmussen, G. S. \& Macdonald, D. W. Small pack size imposes a trade-off between hunting and pup-guarding in the painted hunting dog Lycaon pictus. Ecol. 13, 20-27 (2002).

48. Schneeberger, K. Food sharing and nonhuman reciprocal altruism In Encyclopedia of Evolutionary Psychological Science Publisher (Eds. T.K. Shackelford, V.A. Weekes-Shackelfork) (Springer International Publishing Switzerland Editors, 2016).

49. Estes, R. D. \& Goddard, J. Prey selection and hunting behaviour of the African wild dog. Wildl. Mgmt. 31, 52-70 (1967).

50. Gould, S. J. Kropotkin was no crackpot. Natural History 106, 12- (1997).

51. Dawkins, R. The Selfish Gene (Oxford: Oxford University Press,1976).

52. Teilhard de Chardin, P. The fossils from locality 18, near Peking. Survey China 9(1940).

53. Koufos, G. New Material and Revision of the Carnivora, Mammalia from the Lower Pleistocene Locality Apollonia 1, Greece. Quaternary 1, 6 (2018).

54. Petrucci, M., Cipullo, A., Martínez-Navarro, B., Rook, L. \& Sardella, R. The Late Villafranchian (Early Pleistocene) carnivores (Carnivora, Mammalia) from Pirro Nord (Italy). Abteilung A Palaozoologie Stratigr. 298, 113-145 (2013).

55. Geraads, D. A. A revision of the fossil Canidae (Mammalia) of north-western Africa. Palaeontology 54, 429-446 (2011). 
56. Vislobokova, I. A. \& Agadjanian, A. K. New data on large mammals of the Pleistocene Trlica fauna, Montenegro, the Central Balkans. J. 49, 651-667 (2015).

57. Bishop, M. J. The mammal fauna of the early Middle Pleistocene cavern infill site of Westbury-subMendip, Somerset. Pap. Palaeontol. 28 (1982).

58. Del Campana, D. I cani pliocenici di Toscana. Ital. XIX, 189-254 (1913).

59. Sher, A. V. Olyorian land mammal age of Northeastern Siberia. Palaeontogr. Ital. 74, 97-112 (1986).

60. Von den Driesch, A. A guide to the measurement of animal bones from archaeological sites: as developed by the Institut für Palaeoanatomie, Domestikationsforschung und Geschichte der Tiermedizin of the University of Munich (Peabody Museum Press, 1976).

\section{Figures}

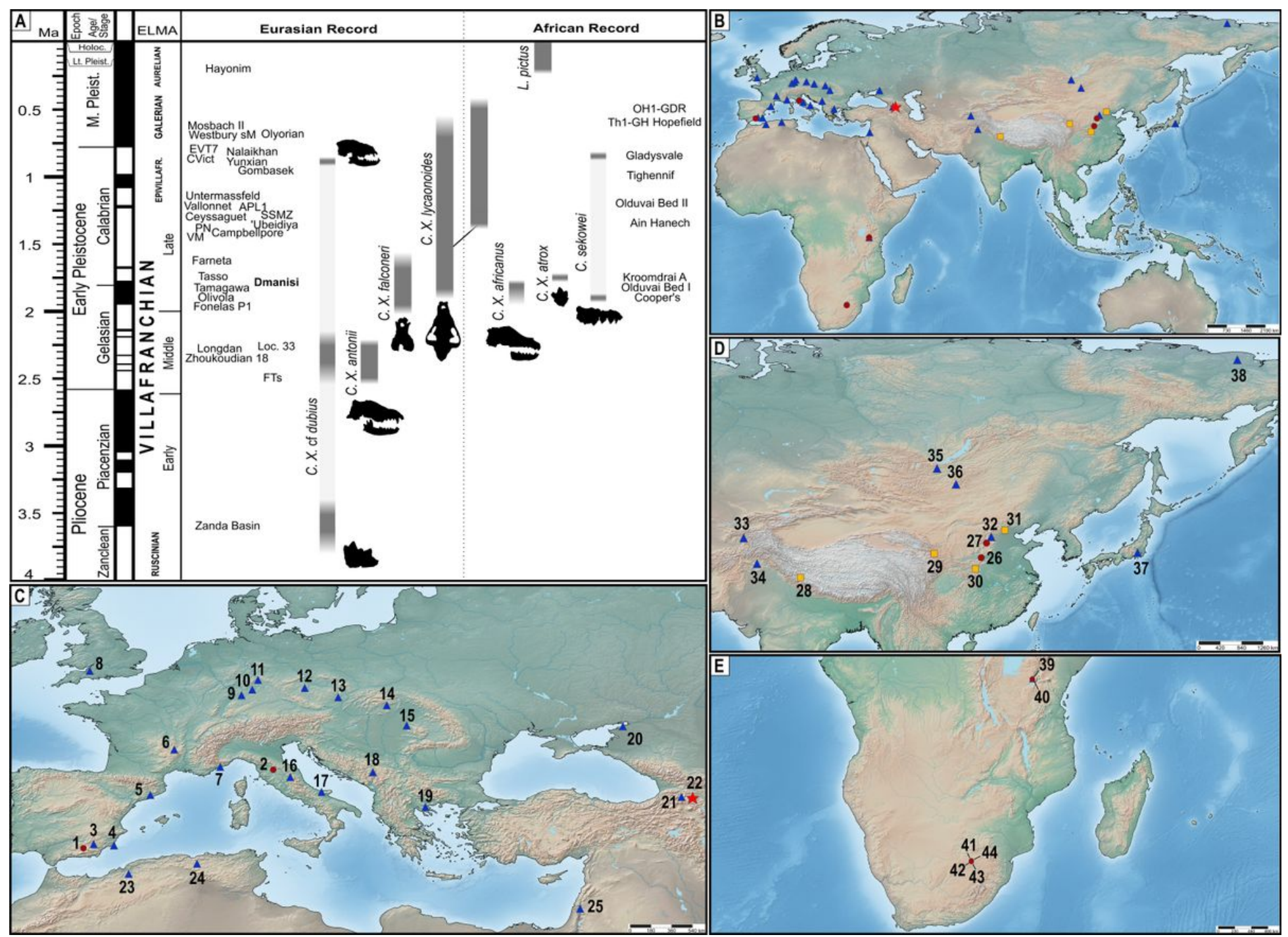

Figure 1

Map and chronology of Canis (Xenocyon) occurrences. A, Resuming chronological scheme of the known occurrences of fossil wild dogs in the Old World. Abbreviations: APL1, Apollonia-1(Greece); CVict, Cueva 
Victoria (Spain); EVT, Vallparadís Estació (Spain); FTs, Fan Tsun (China); OH1-GR1, Oulad Hamida1-Grotte des Rhinoceros (Morocco); PN, Pirro Nord (Italy); SSMZ, Shanshenmiaozui (China); Th1-GH, Thomas 1 Quarry-Grotte des Hominides (Morocco); VM, Venta Micena (Spain); Westbury sM, Westbury-sub-Mendip (Great Britain). B-E, Maps showing the Old-World occurrences of fossil wild dogs described in the text. (CE detailed view of respectively Europe and Circum-Mediterranean area, eastern Asia and southeastern Africa). Localities: 1, Fonelas-P1 (Spain); 2, Upper Valdarno (Italy); 3, Venta Micena (Spain); 4, Cueva Victoria (Spain); 5, Vallparadís Estació (Spain); 6, Ceyssaguet (France); 7, Vallonnet (France); 8, Westburysub-Mendip (Great Britain); 9, Mosbach II (Germany); 10, Würzburg-Schalksberg (Germany); 11, Untermassfeld (Germany); 12, Koněprusy C178 (Czech Republic); 13, Stránská Skála (Czech Republic); 14, Gombasek (Slovakia); 15, Betfia (Romania); 16, Collecurti (Italy); 17, Pirro Nord (Italy); 18, Trlica (Montenegro); 19, Apollonia-1 (Greece); 20, Margaritovo (Russia); 21, Akhalkalaki (Georgia); 22, Dmanisi (Georgia); 23, Tighennif/Terfine (Algeria); 24, Ain Hanec (Algeria); 25, 'Ubeidiya (Israel); 26, Loc. 33 in Zdansky (1924) (China); 27, Fan Tsun/Taigu (China); 28, Zanda Basin (China); 29, Longdan (China); 30 , Yunxian (China); 31, Zhoukoudian 18 (China); 32, Ma Fang (China); 33, Lakhuti-2 (Tajikistan); 34, Campbellpore (Pakistan); 35, Zasukino (Russia); 36, Nalaikhan (Mongolia); 37, Tamagawa (Japan); 38, Olyorian fauna (Russia); 39, Olduvai bed I (Tanzania); 40, Olduvai bed II (Tanzania); 41, Cooper's Cave (South Africa); 42, Kroomdrai A (South Africa); 43, Gladysvale (South Africa); 44, Hopefield (South Africa). Symbol and colors code is: red star, Dmanisi site; dark red circles, C. (Xenocyon) ex gr. falconeri; blue triangles, C. (Xenocyon) lycaonoides; yellow squares, C. (Xenocyon) dubius. Note: The designations employed and the presentation of the material on this map do not imply the expression of any opinion whatsoever on the part of Research Square concerning the legal status of any country, territory, city or area o bbnhjr of its authorities, or concerning the delimitation of its frontiers or boundaries. This map has been provided by the authors. 

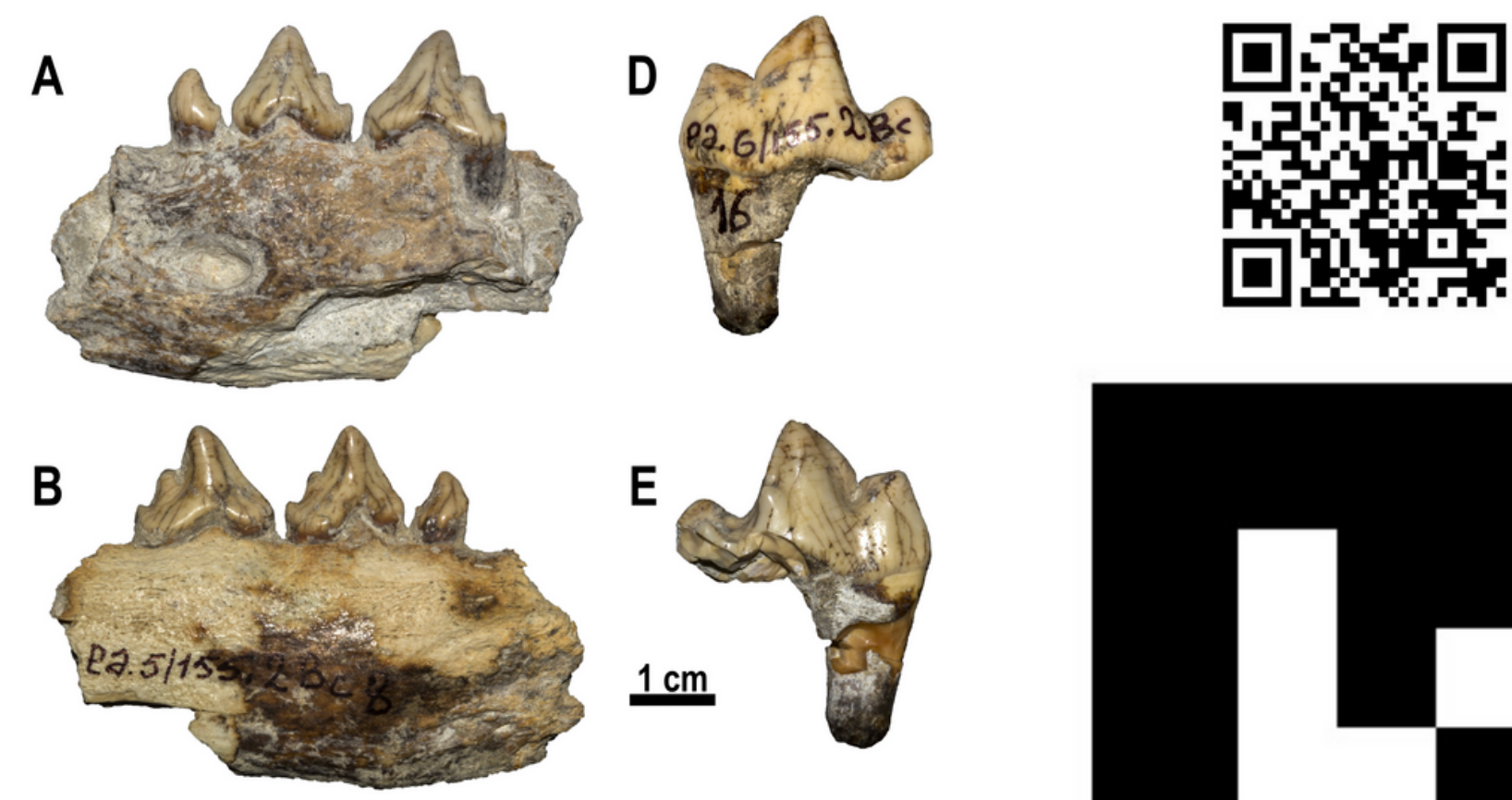

C
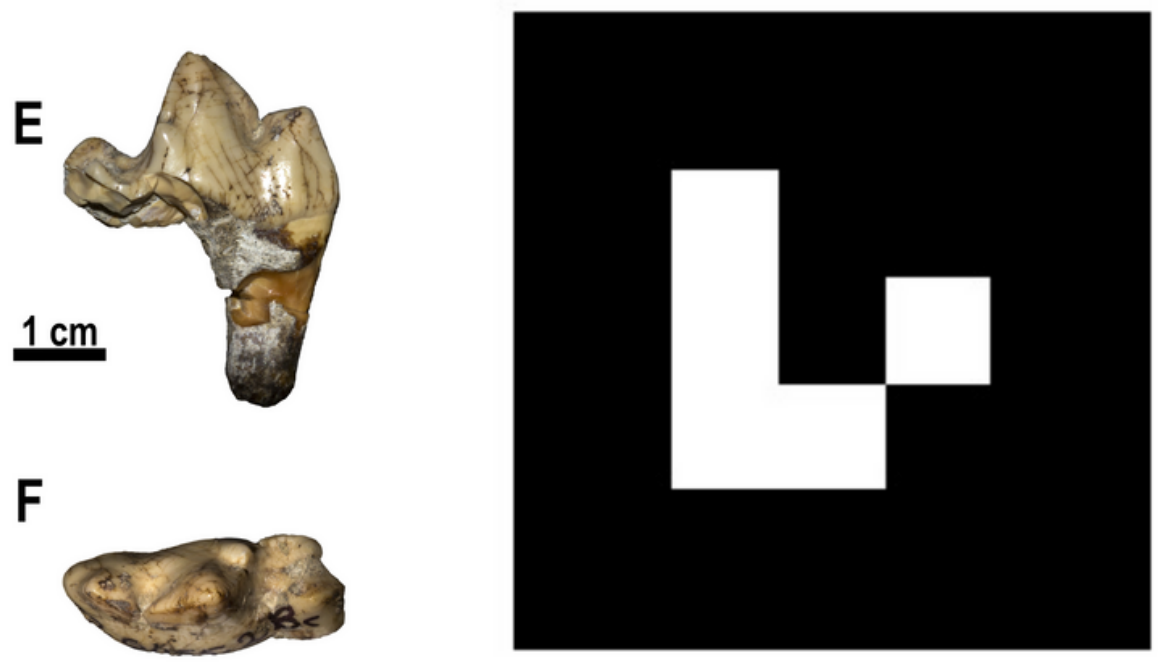

Figure 2

Canis (Xenocyon) lycaonoides from Dmanisi. A-C, D6327a, left corpus with p1-p3 in buccal (A), lingual (B) and occlusal (C) views. D-F, D6327b, left lower m1 in buccal (D), lingual (E) and occlusal (F) views. QR code and Augmented Reality (AR) marker showing 3D comparison between the lower first molar morphologies of Canis (Xenocyon) from Dmanisi (red), Canis (Xenocyon) lycaonoides from Venta Micena (green) and Canis (Xenocyon) falconeri from Upper Valdarno (gray). Instructions: Scan the QR code on the left; open the link; allow the browser to access the camera of your device; point the camera toward the marker (on the right); and wait for the model to load (up to 10 seconds). It is possible to turn the device around the marker (or to move the marker) to see different parts of the model. Best visualization performances can be achieved by printing the markers, rather pointing at them on screens. Refer to Bartolini Lucenti et al. (2020) for common issues.

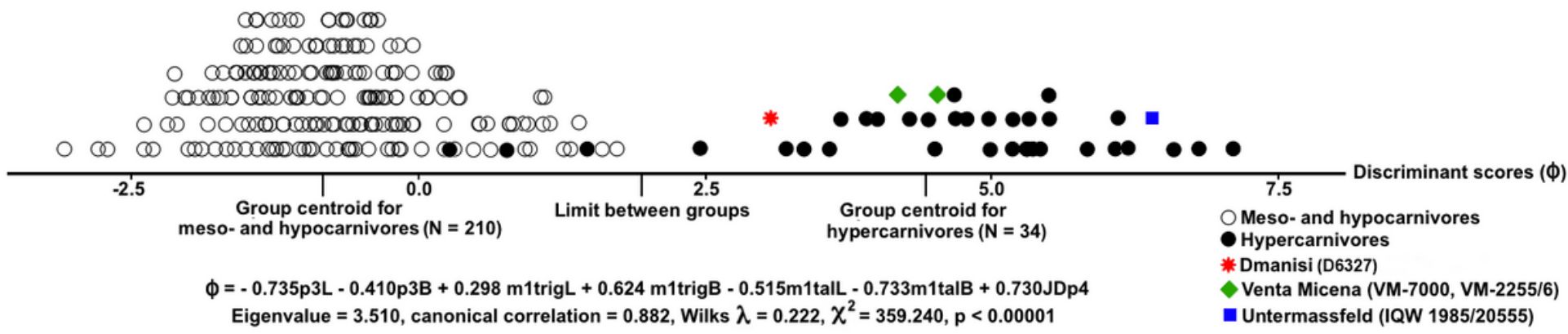

Figure 3 
Discriminant analysis using metric measurements of lower teeth ( $\mathrm{p} 3$ and $\mathrm{m} 1$ ) and jaw between the living omnivorous (i.e., meso- and hypocarnivorous) and hypercarnivorous canids. The scores of the fossil specimens, including Dmanisi, Venta Micena and Untermassfeld, are shown.
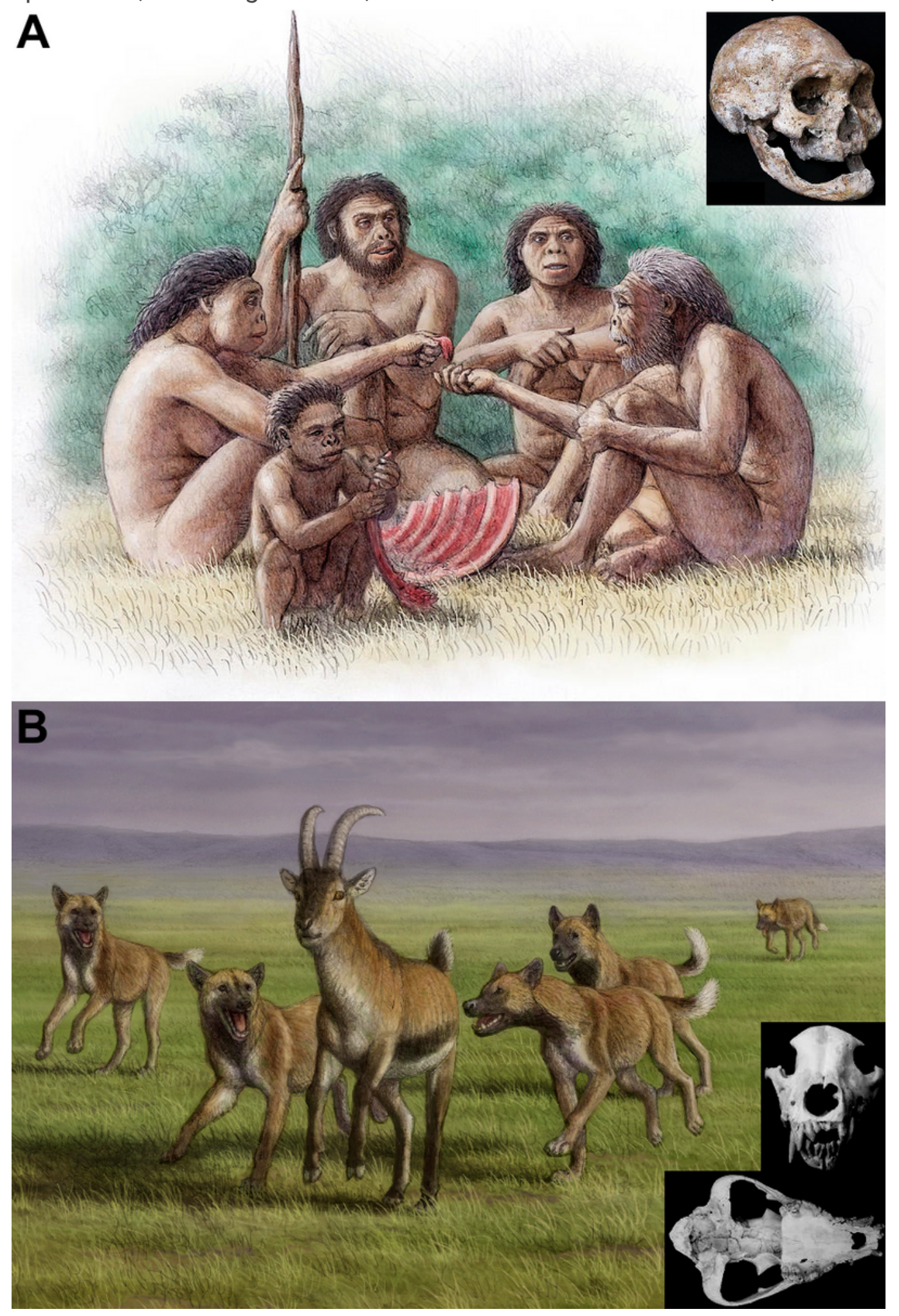

Figure 4

Two social species at Dmanisi. A: reconstruction by Mauricio Antón of altruistic behaviour of a group of Homo erectus sharing food with an individual who lived several years without teeth (as evidenced by 
edentulous skull D3444 and associated mandible D3900). This severe masticatory impairment would limit the diet of the individual to foodstuffs that did not require heavy chewing (e.g., soft plants, animal brain and marrow) or that were orally processed before by others. B: reconstruction by Mauricio Antón of a pack of hunting dogs chasing a prey by at Venta Micena, a site where a pathological skull (cranium and associated mandible VM-7000) of Canis (Xenocyon) lycaonoides showing marked bilateral asymmetry and agenesia of several teeth was unearthed. The disabled dog, whose absence of an upper canine probably made it useless for hunting is drawn running far behind the pack. Given that the individual managed to survive until a relatively advanced age, as indicated by tooth wearing, this suggests that the other members of its family group would have allowed it to feed on the prey captured by the hunting pack. Remains of this hypercarnivorous canid species are also preserved in the assemblage of large mammals from Dmanisi, as shown in this paper.

\section{Supplementary Files}

This is a list of supplementary files associated with this preprint. Click to download.

- SIBartolinietalSR.docx

- FigureS1.tif

- FigureS2.tif

- TabS1.xlsx 